Al-Madrasah: Jurnal Ilmiah Pendidikan Madrasah Ibtidaiyah

Vol. 6, No. 1, 2021

DOI 10.35931/am.v6i1.533

P-ISSN: 2620-5807; E-ISSN: 2620-7184

\title{
POLA ASUH ORANG TUA “ZAMAN NOW” TERHADAP KETERAMPILAN BERBICARA ANAK USIA DASAR
}

\author{
Muhammad Majdi \\ Dosen, Sekolah Tinggi Ilmu Al-Quran (STIQ) Amuntai, Kalimantan Selatan \\ Email: Muhammadmajdi755@gmail.com \\ Hj. Rahimah \\ Dosen, IAI Darussalam Martapura, Kalimantan Selatan \\ Email: hjrahimahpiaud@gmail.com \\ Muzdhalifah \\ Dosen, STAI Darul Ulum Kandangan, Kalimantan Selatan \\ Email: Muzdhalifah2711955@gmail.com
}

\begin{abstract}
ABSTRAK
Pola asuh orang tua "zaman now" adalah pola asuh orang tua pada masa pandemi (Covid-19) yang mengalami pergeseran karena segala aktivitas pendidikan anak dilakukan secara online artinya akan berpengaruh pada pola asuh orang tua, tidak terkecuali terhadap keterampilan berbicara anak. Keterampilan berbicara tersebut memiliki dampak, karena pada dasarnya anak senang bermain dan berinteraksi yang mana banyak dihabiskan di Sekolah. maka dari itu pola asuh orang tua penting bagi tumbuh-kembangnya keterampilan anak pada masa sekarang. Penelitian menggunakan penelitian kualitatif dengan pendekatan induktif, subjek dalam penelitian adalah beberapa orang tua yang memiliki anak pada tingkat Sekolah dasar atau Madrasah Ibtidaiyah dampak Covid-19. Hasil penelitian dari 6 narasumber ditemukan bahwa pola asuh orang tua berbeda-beda. Hasilnya dijabarkan sebagai berikut: Narasumber 1 pola asuh Demokratis, narasumber 2 pola asuh Otoriter, narasumber 3 pola asuh Autoritatif, narasumber 4 pola asuh Demokratis, narasumber 5 pola asuh permisif, dan narasumber 6 pola asuh Demokratis dan Permisif. Hasil yang berbeda terjadi pada Narasumber yang ke-5 berdampak negatif karena kurang tegas dan kurang seimbangnya pengaruh orang tua sehingga orang tua dibawah kendali anak.
\end{abstract}

Kata Kunci: Pola Asuh Orang Tua, "Zaman Now", Keterampilan Berbicara Anak Usia Dasar.

\section{A. Pendahuluan}

Umumnya Keterampilan Berbicara termasuk dari empat komponen keterampilan dalam mata pelajaran Bahasa Indonesia yaitu keterampilan menulis, membaca, berbicara, dan menyimak. ${ }^{1}$ Yeti Mulyati dalam bukunya menjelaskan bahwa kegiatan berbicara 1986), hlm. 1.

${ }^{1}$ Henry Guntur Tarigan, Menulis: sebagai Suatu Keterampilan Berbahasa (Bandung: Angkasa, 
Muhammad Majdi, Hj. Rahimah, Muzdalifah : Pola Asuh Orang Tua "Zaman Now” Terhadap Keterampilan Berbicara Anak Usia Dasar

adalah sesuatu yang dilakukan untuk menyampaikan pesan kepada orang dengan bahasa lisan. Tujuan secara umum dari kegiatan berbicara di SD/MI terbagi menjadi 2 jenis yaitu kelas rendah dan kelas tinggi, 1) Kelas rendah: a) stimulus keberanian, b) stimulus dalam menyampaikan sebuah pengetahuan dan pengalaman, c) stimulus penyamapaian pendapat/kritik, d) pembiasaan siswa agar berani bertanya. Sedangkan 2) bagi kelas tinggi: a) membina keberanianya, b) menyampaikan pengetahuan umum/khusus siswa, c) stimulus siswa untuk beradu argumen, d) stimulus siswa dalam ketajaman cara berpikir, e) stimulus dalam menghargai pendapat orang. ${ }^{2}$

Pola Asuh zaman Now yang dimaksud pada judul adalah Pola Asuh orang tua pada masa Pandemi (Covid-19) yang mengalami pergeseran karena segala aktivitas pendidikan anak yang awalnya dilakukan di sekolah dan sekarang harus dilaksanakan di rumah yang mana nantinya juga akan berdampak pada pola asuh orang tua terhadap keterampilan berbicara, karena secara tidak sadar aktivitas anak di sekolah akan berdampak baik terhadap keterampilan berbicara anak sedangkan pada masa sekarang anak banyak menghabiskan waktu di rumah. Peran orang tua tidak hanya menemani anak bermain tetapi juga memberikan pendidikan untuk anak sesuai dengan perkembangan zaman sekarang. Peran orang tua memiliki peranan yang sangat penting dalam memberikan pendidikan atau pemahaman yang berhubungan dengan covid atau pandemi yang sedang mewabah untuk tetap berdiam diri dirumah tidak tertular atau menularkan wabah pandemi ini. Para orang tua akan memiliki peran yang sangat penting dalam pemeberian pemahaman tersebut.

Ketika virus corona masuk dan menyebar di wilayah indonesia, hal tersebut membuat pemerintah mengeluarkan peraturan tegas agar wabah corona tidak menyebar lebih luas. Karena yang kita ketahui bersama bahwa virus corona ini dapat menyebar sangat cepat bahkan sudah memakan korban jiwa diberbagai negara termasuk indonesia. Sehingga pemerintah melakukan berbagai cara untuk mencegah penyebaran secara luas, salah satu yang dilakukan pemerintah yaitu dengan menerapkan pembelajaran secara online atau jarak jauh, dimana siswa ataupun mahasiswa tidak diizinkan untuk berinteraksi tatap muka dengan skala besar.

Sebelumnya Pola asuh ialah sebuah cara yang dilakukan oleh para orang tua dalam memberikan dorongan dalam membantu anak mencapai suatu tujuan yang diinginkan dan dicita-citakan anak. penanaman pola asuh pada anak diharapkan mempu membentuk pribadi anak yang baik dan berakhlakul qarimah, penuh semangat dalam menuntut ilmu sehingga memiliki prestasi yang cemerlang di bidangnya seiring pertumbuhan dan perkembangan yang dialami oleh anak. ${ }^{3}$ pola asuh asuh yang dilakukan

${ }^{2}$ Solchan T.W., Pendidikan Bahasa Indonesia di SD, (Banten: universitas terbuka press, 2014), hlm. 11.20-11.22.

${ }^{3}$ E Lestari dan R Auliana, Hubungan Pola Asuh Orang Tua dengan Prestasi Belajar Siswa Konsentrasi Patiseri SMK Negeri 1 Sewon, Bantul. Jurnal Pendidikan , Http://eprints.uny.ac.id/10617/1/JurnalErmaLestari/pdf. Diakses 13 Januari 2021 
Muhammad Majdi, Hj. Rahimah, Muzdalifah : Pola Asuh Orang Tua "Zaman Now” Terhadap Keterampilan Berbicara Anak Usia Dasar

orang tua kepada anak memiliki pengaruh terhadap perkembangan motorik halus dan kasar, perkembangan sosial emosional serta perkembangan bahasa anak. ${ }^{4}$

Beberapa fase yang mengarah pada tumbuh kembang anak memiliki kreteria dan tugas perkembangan seperti kemampuan bahasa, perkembangan anak tersebut dilihat dari keinginan anak dalam bermain, keinginan untuk berpetualang, serta imajinasi yang diciptakan anak sebagai dari prilaku anak. ${ }^{5}$

Terdapat faktor yang mempengaruhi pola asuh yang dilakukan oleh orang tua kepada anak menurut Harlock, yakni sifat dan pembawaan orang tua yang berbeda-beda, kesabaran, pengetahuan, perilaku dan kematangannya untuk mejadi seorag ibu. Faktor tersebutlah yang nanti akan membawa dampak atau pengaruh dalam memenuhi kebutuhan anak-anaknya. Pemahaman serta keyakinan orang tua dalam mengasuh juga akan mempengaruhi tingkah laku anak anaknya. ${ }^{6}$

Keserasian yang pola asuh orang terima dari orang tuanya seperti orang tua merasa bahwa mereka dulu berhasil menerapkan pola asuhnya kepada anak nya dengan baik, maka merekapun para orang tua akan mencontoh pola asuh tersebut secara turun temurun. Jika pola asuh tersebut dirasa kurang tepat maka mereka akan menggunakan pola asuh yang disepakati oleh kelompok orang tua yang juga memiliki anak (keluarga besar ataupun kecil).

Pada pelaksanaannya guru ataupun pendidik selalu mencoba untuk memenfaatkan teknologi dalam menyikapi pembelajaran jarak jauh/online. Akan tetapi pembelajaran tersebut tidak lah selalu berjalan lancar. Banyak sekali kendala yang dihadapi orang tua, guru, dan anak dalam mengakses internenet seperti sinyal yang tidak memadai, dan tidak menutup kemungkinan anak tidak memiliki handphone yang memadai. Sehingga materi yang diberikan tidak tersampaikan dengan baik, sehingga anak lah yang terdampak dari kegagalan pembelajaran tersebut, anak akan merasa tidak terbimbing karena kurangnya pemahaman anak terhadap pembelajaran yang diberikan secara online tersebut. ${ }^{7}$

Sehingga fungsi orang tua dalam pola asuh anak sangat berperan penting sebagai pengganti guru dilingkungan rumah. Pendapat Winingsih, terdapat peran orang tua dalam pembelajaran jarak jauh, yaitu orang tua memiliki peran sebagai guru dilingkungan rumah, orang tua sebagai fasilitator anaknya, orang tua sebagai penyemangat dalam pembelajaran online agar dapat berjalan dengan baik dan tepat sasaran, dan orang tua sebagai role model untuk anaknya. ${ }^{8}$

Seperti yang telah dijelaskan di atas bahwa pada zaman sekarang orang tua yang lebih berperan dalam mengembangkan berbagai keterampilan anak, terutama

${ }^{4}$ Rabiyatul Adawiyah, Poa Asuh Orang Tua dan Implikasinya Terhadap Pendidikan Anak, FKIP ULM Banjarmasin, Jurnal pendidikan, Http://pola-asuh-orang-tua-dan-implementasinya-ter/pdf. Diakses 13 Januari 2021

${ }^{5}$ Sumiati dkk, Kesehatan Jiwa Remaja Dan Konseling, (Jakarta: Trans Info Media, 2014), hlm. 89 ${ }^{6}$ Hurlock, Perkembangan Anak, (Jakarta:Erlangga, 1978), hlm. 151

${ }^{7}$ Rita Cahyati dan Rita Kusumah, Peran Orang Tua Dalam Menerapkan Pembelajaran di Rumah Saat Pandemi Covid 19, PG PAUD STIKIP Muhamadiyah Kuningan, Vol.04 No 1 diakses 13 Januari 2021, hlm. 152

${ }^{8}$ Ibid, hlm, 153

Al-Madrasah: Jurnal Ilmiah Pendidikan Madrasah Ibtidaiyah Vol. 6, No. 1, Juli-Desember 2021 
keterampilan berbicara apakah sama dengan aktifnya di sekolah dan di rumah, masa pedemi ini anak lebih aktif belajar di rumah dengan bimbingan orang tua, namun perlu kita ketahui dari berbagai banyak anak nyatanya berbeda-beda bimbingan atau pengasuhan orang tua dalam mendidik anak-anaknya.

Ada berbagai macam permasalahan yang saat ini lagi viral bagi orang tua dalam mendidik anak-anaknya terutama membimbing anak di rumah dalam belajar. Yaitu, orang tua yang mengeluhkan kepada guru karena mereka tidak bisa membaca sehingga berdampak kepada anak tidak bisa belajar,ini termasuk pola pengasuhan otoriter, orang tua yang mengaku sibuk dengan pekerjaannya dan tidak sempat membimbing anaknya belajar, ini termasuk pola asuh penelantar, orang tua yang tidak sanggup mengejar anak dikarenakan anak yang susah untuk dia atur, ada juga anak yang tidak peduli kepada orang tuanya dikarenakan belajar hanya sendiri tidak ada temannya, sehingga anak-anak mereka hanya bermain di luar rumah tanpa mau belajar di rumah, ini termasuk pola asuh orang tua penyabar.

Dari permasalahan di atas ada banyak berbagai macam pola asuh yang diterapkan orang tua, setiap orang tua dalam mendidik anaknya mempunyai pola asuh yang berbedabeda semuanya tidak sama.

Ada beberapa tipe pola asuh yang bisa diterapkan oleh orang tua untuk anaknya. Berikut adalah tipe-tipe pola asuh orang tua:

1. Pola asuh Ototiter, Pola asuh dengan pola komunikasi satu arah. Dengan ciri-ciri pola asuh yang menitikberatkan bahwa aturan orang tua harus ditaati. ${ }^{9}$

2. Pola asuh Tipe Autoritatif, Orang tua ini memiliki daya kendali yang tinggi dan mengharuskan anak-anaknya bertindak pada tingkat intelektual dan sosial sesuai dengan usia dan kemampuan mereka. Orang tua tipe jenis ini akan sepenuhnya menerima dan melibatkan anak.. ${ }^{10}$

3. Pola Asuh Permisif, pola asuh yang menitikberatkan kebebasan. Anak dibebaskan untuk melakukan apa yang dia kehendaki. Kelemahannya adalah lemahnya kontrol dari orang tua serta tidak memberikan bimbingan yang cukup bagi anak. Yang dilakukan anak itu dianggap benar tidak perlu mendapatkan teguran, arahan atau bimbingan. Kelebihannya orang tua tipe ini bersifat hangat dan disukai oleh anak. ${ }^{11}$

4. Pola Asuh Demokratis, ditandai dengan memberikan pendapat mendengarkan pendapat karena orang tua sedikit memberi kebebasan untu anak memilih apa yang terbaik bagi dirinya. Orang tua mendengarkan pendapat anaknya, dan juga dilibatkan dalam pembicaraan umum atau masalah anak pada khususnya. ${ }^{12}$

Kembali lagi bahwa Peserta didik pada hakikatnya terbentuk oleh lingkungan disekitar atau pola asuh orang tua yang diterapkan. Kesulitan berbicara pada Anak Usia Dasar yaitu 1) susah dalam mengingat sebuah kata, 2) keraguan ucapan tentang kata tersebut, 3) tidak percaya diri.

\footnotetext{
${ }^{9}$ Maimunah Hasan, Pendidikan Anak Usia Dini, (Yogyakarta : DIVA Press, 2009), hlm. 19

${ }^{10}$ Ibid., hlm. 84.

${ }^{11}$ Muhyani, Pengaruh Pengasuhan Orang Tua dan Peran Guru Di Sekolah Menurut Persepsi Murid Terhadap Kesadaran Religius dan Kesehatan Mental (Jakarta: Kementrian Agama Republik Indonesia, 2012), hlm. 87

${ }^{12}$ Hasanatul Jannah, "Bentuk Pola Asuh Orangtua Dalam Menanamkan Perilaku Moral Pada Anak Usia Dini di Kecamatan Ampek Angkek", dalam Jurnal PG-PAUD FIP, Universitas Negeri Padang, 2016, hlm. 4
} 
Solusi yang tepat adalah sebagai berikut. 1) awali pembicaraan dengan pengenalan tema, 2) kerangka bicara (teks), 3) latihan bicara menggunakan cermin, 4) latihan bicara dengan teman sebaya. ${ }^{13}$

Karena pada dasarnya Kemampuan berbahasa anak usia dasar itu berbeda-beda ada yang pendiam, berani, kental dengan bahasa daerah, serta tidak berani dalam menyampaikan pendapat. Proses pengembangan keterampilan verbal atau berbicara cara mempengaruhi faktor internal dan eksternal. Faktor internal lingkungan sekolah. Faktor eksternal yaitu di rumah dengan gambar pedoman oleh pola asuh orang tua. Hal yang paling penting untuk mengembangkan keterampilan verbal nya atau keterampilan berbicara nya yaitu dengan cara menci ptakan suasana yang menyenangkan bagi siswa di sekolah ataupun di rumah yaitu dengan poa asuh orang tua yang tepat.

\section{B. Metode Penelitian}

Penelitian menggunakan penelitian kualitatif, yaitu menggambarkan keadaan di lapangan. Sedangkan pendekatan yang digunakan ialah bersifat induktif yang mana peneliti membiarkan masalah-masalah berkembang dari data. Data dikumpulkan dan dideskripsi serta dianalisis dari hasil observasi dan wawancara secara mendalam. ${ }^{14}$ Subjek dalam penelitian adalah beberapa orang tua yang memiliki anak pada tingkat sekolah dasar atau madrasah ibtidaiyah dampak Covid-19. Metode analisis data yang diterapkan adalah data kualitatif Cresswell dengan mengikuti prosedur sebagai berikut: 1). Mengatur dan mempersipakan data yang akan dianalis, 2). Membaca, memahami, dan melihat semua data terkait pola asuh "zaman now" yang diterapkan oleh para orang tua dalam menjaga dan mengembangkan keterampilan berbicara anak, 4). Hubungan antar tema terkait, dan 5). Memberikan interpretasi tentang tema dalam penelitian. ${ }^{15}$

\section{Hasil Penelitian Dan Pembahasan}

Penelitian yang dilakukan bersifat dinamis sesuai dengan data yang dibutuhkan yaitu pola asuh orang tua "zaman now" terhadap keterampilan berbicara anak. Pola asuh orang tua "zaman now" yang dimaksud adalah pola asuh orang tua pada masa sekarang yaitu pada masa pandemi (Covid-19) yang mengalami pergeseran karena segala aktivitas pendidikan anak dilakukan secara online artinya berdampak pada pola asuh orang tua tersebut tidak terkecuali terhadap keterampilan berbicara anak. Keterampilan berbicara tersebut memiliki efek yang terasa, karena pada dasarnya anak senang bermain dan berinteraksi yang banyak dihabiskan di Sekolah. maka dari itu pola asuh orang tua penting bagi tumbuh-kembangnya keterampilan anak pada masa sekarang.

\section{Narasumber ke-1}

Hasil dari observasi dan wawancara peneliti, narasumber 1 yang berinisial A berprofesi sebagai guru yang mempunyai anak J sekolah di MIN kelas 2. Dalam hal pola asuh orang tua Narasumber A cenderung orang tua yang memberi kesempatan untuk tidak selalu tergantung kepada orang tua dengan kata lain yaitu mandiri. Hal ini sesuai dari

\footnotetext{
${ }^{13}$ Isah Cahyani, modul pembelajaran bahasa Indonesia, (Jakarta: direktorat jenderal pendidikan Islam, 2012), hlm. 79.

${ }^{14}$ Nana Syaodih Sukmadinata, Metode Penelitian Pendidikan, (Bandung: Remaja Rosdakarya,2015), hlm. 60.

${ }^{15}$ Sugiyono, Metode Penelitian Kualitatif untuk Penelitian yang Bersifat: Eksploratif Interaktif dan Konstruktif ( Bandung: Alfabeta, 2017), hlm. 162-163.
} 
pernyataan pada jurnal Hasanatul Jannah yaitu Orang tua sedikit memberi kebebasan kepada anak.

Pola asuh demikian sesuai dengan prinsip dari pola asuh orang tua Demokratis yang dapat dilihat dari indiktor pola asuh orang tua demokratis. Euis Sunarti mengelompokkan menjadi beberapa pola indikator 1) Pola Komunikasi 2) Pola Bimbingan, 3) Pola Motivasi. ${ }^{16}$

Pola Komunikasi terdiri dari keterbukaan, perasaan positif dan kesamaan. Hasil dari observasi peneliti mengamati bahwa terjadi pola komunikasi yang menarik antara orang tua dengan anak (Narasumber A dengan J). Terlebih dahulu orang tua menanamkan pola komunikasi dan perasaan yang positif dengan memberikan "doktrin" bahasa, artinya anak tidak boleh berkata kasar dari cara berkomunikasi dengan teman sebaya, teman berbeda umur, dan kepada orang tua dll. Pola tersebut ditanamkan dan diamalkan dalam keseharian sampai menjadi suatu kebiasan dalam keluarga tersebut. Dari hal tersebut menanamkan keberanian berbahasa yang santun kepada anak, artinya anak tidak hanya dibekali keterampilan berbicara dengan unsur keberanian saja tetapi keberanian serta diiringi keterampilan berbicara yang santun terhadap semua kalangan. Hal ini terjadi atas pola komunikasi yang baik dan orang tua menjadi role model bagi perkembangan berbahasa anak.

Pola Bimbingan terdiri dari Keteladanan, Pemberian nasehat, dan Pengawasan. Hasil dari observasi peneliti mengamati pada interaksi bimbingan orang tua dengan anak berjalan dengan positif artinya orang tua menyampaikan tegurannya atau pemberian nasehat dan pengawasan dengan berkata baik/positif sehingga terjadi keterbukaan antar anak dengan orang tua. Seperti kalimat orang tua dalam melarang anak, orang tua sebaiknya memberikan pengertian bukan kalimat larangan dengan mengatakan "tidak" karena dengan kalimat memberikan pengertian, anak secara tidak langsung dapat memahami maksud dari perkataan orang tua. Bukan halnya memberikan kalimat negatif seperti langsung mengatakan "tidak" tanpa memberikan keterangan kepada anak. Hal ini berdampak kepada kepercayaan diri anak meningkat, artinya walaupun aktivitas kebanyakan dirumah tetapi karena adanya pola bimbingan yang baik antara anak dengan orang tua maka anak akan lebih dekat kepada orang tua dan keterempilan berbicaranya terasah seperti dapat menceritakan pengetahuan dan pengalamannya ,anak dapat menyampaikan pendapatnya serta anak tidak malu untuk bertanya. Hal ini sesuai dengan indikator keterampilan berbicara pada anak kelas rendah. Dibuktikan dengan hasil wawancara kepada anak bahwa anak merasa senang dan tidak malu untuk bercerita kepada orang tua serta bertanya.

Sedangkan Pola Motivasi terdiri dari Penghargaan dan Hukuman. Hasil observasi dan wawancara bentuk penghargaan pada keluarga tersebut terdiri dari verbal dan nonverbal. Verbal dengan kalimat pujian atas hasil yang dicapai dari hal yang bersifat kecil sampai besar. Sedangkan nonverbal dengan memberikan gestur sentuhan kasih sayang atas yang dicapai. Orang tua sengaja tidak membiasakan dengan memberikan benda ataupun berbentuk uang karena akan berdampak negatif dikemudian hari yang selalu berorientasi kepada hadiah dan keuntungan.

\section{Narasumber ke-2}

Selanjutnya Hasil dari observasi dan wawancara peneliti, narasumber 2 yang berinisial I berprofesi sebagai Ibu Rumah Tangga yang mempunyai anak S sekolah di SD

\footnotetext{
${ }^{16}$ Euis Sunarti, Mengasuh Dengan Hati, (Bandung: Elax Media Komputindo, 2004), hlm.118
} 
kelas 1. Dalam hal pola asuh orang tua Narasumber I cenderung orang tua yang menggunakan pola komunikasi satu arah. Sesuai penjelasan dari Maimunah Hasan dalam bukunya menjelaskan keluarga yang menerapkan pengasuhan ini komunikasi antara orang tua dan anak berlangsung searah dan hubungan terlihat kaku dan tidak harmonis.

Pola asuh demikian sesuai dengan prinsip dari pola asuh orang tua Otoriter yang dapat dilihat dari indiktornya. Euis Sunarti mengelompokkan menjadi beberapa pola indikator 1) Anak harus mematuhi peraturan-peraturan orang tua dan tidak membantah, 2) Orang tua cenderung mencari kesalahan-kesalahan anak dan kemudian menghukumnya, 3) Orang tua cenderung memberikan perintah dan larangan kepada anak, 4) Orang tua cenderung memaksakan disiplin, 5) Orang tua cenderung memaksakan segala sesuatu untuk anak dan anak hanya sebagai pelaksana, tidak ada komunikasi antara orang tua dan anak. ${ }^{17}$

Hasil observasi dan wawancara dengan nerasumber 2 bahwa pola asuh yang diterapkan adalah pola asuh otoriter tertapi tidak mencakup semua indikator. 1) Anak harus mematuhi peraturan-peraturan orang tua dan tidak membantah, 2) Orang tua cenderung memaksakan disiplin.

Anak harus mematuhi peraturan-peraturan orang tua dan tidak membantah, hasil dari observasi dan wawancara peneliti mengamati pada indikator ini bahwa orang tua membiasakan kepada anak mengatur pola aktivitasnya sehari-hari atau terjadwal, dari jadwal sarapan, belajar, megang hp, ibadah serta bermain. hal ini berbuah positif karena karakter anak sesuai atau cocok dengan pola asuh yang dibawakan orang tua tersebut. Sehingga terjadi pola komunikasi yang baik dan menjadikan anak menjadi pribadi yang positif. Khususnya kepada kebahasaan anak dalam kaitan ini adalah keterampilan berbicara anak. Anak lebih berani dan percaya diri karena menganggap orang tua perhatian dan sayang kepada dirinya. Demikian pola asuh ini berkerja dengan baik.

Orang tua cenderung memaksakan disiplin, hasil dari observasi dan wawancara peneliti mengamati pada indikator ini bahwa orang tua menjalankan indikator yang pertama tadi awalnya dengan cara memaksanakan disiplin. Salah satu caranya adalah dengan memberikan sanksi yang mendidik. Sanksi utama yaitu membaca al-Quran, dan ada sanksi tambahan yaitu tidak memberikan izin menggunakan hp dan tidak diberikan uang jajan. Khusus untuk sanksi tambahan akan terputus apabila anak bersedia meminta maaf dan tidak mengulanginya kembali. Hasilnya anak terbiasa dengan pola tersebut dan membentuk keterampilan berbicara anak dalam hal melatih anak dalam menyampaikan pendapat dan keterampilan dalam bercerita serta bertanya. Dari interaksi pemberian sanksi tersebut terdapat pelajaran apabila melakukan kesalahan harus meminta maaf serta amanah dan tanggung jawab atas ucapannya tidak mengulangi kembali.

\section{Narasumber ke-3}

Hasil dari observasi dan wawancara peneliti, narasumber ke-3 yang berinisial $\mathrm{M}$ berprofesi sebagai penjual mie ayam yang mempunyai anak 1 orang, anak ini termasuk sudah berada di kelas tinggi yaitu kelas $6 \mathrm{SD}$, orangtuanya mengatakan selama sekolah di masa pendemai ini, anak ini sekolahnya satu kali dalam seminggu, dan di rumah tidak dapat membimbing anak dalam belajar dikarenakan sibuk bekerja. Maka salah satu cara agar anak dapat bimbingan dalam belajar di rumah yaitu dengan acara diberikan privat ke rumah seorang pengajar.

\footnotetext{
${ }^{17}$ E.B, Surbakti, Parenting Anak, (Jakarta: Kompas Gramedia, 2012), hlm. 07
} 
Orangtua ini mengatakan bahwa anaknya ketika di sekolah keaktifan dalam berbicaranya kurang, dan di saat masa pendemi ini dalam belajar di rumah pun kurang aktif dalam berbiacaranya. Cara orangtua anak ini membimbing anak dalam belajar dengan harus dipaksa dulu baru anak ini mau belajar, namun balik paksaan tersebut anak akan mau belajar, kalau tidak dipaksa maka dia akan malas, orangtuanya mengatakan mereka tidak kasar dalam mendidik, namun dikarenakan ingin anak tetap belajar maka harus dengan cara sesuai sifat anak cara memerintah. Artinya anak ini belajar dengan bimbingan orangtua bersifat pola asuh Autoritatif orangtua memberikan arahan pengendalian yang tinggi dan mengharuskan anak-anaknya bertindak cepat belajar sesuai dengan kemampuanya, namun ada kehangatan, bimbingan dua arah yang berlawanan dari orangtua dan anak tersebut.

Berkaitan dengan indikator berbicara bahwa anak ini berada di kelas tinggi, keterampilan berbicara atau tujuan pembelajaran dalam mengembangkan berbicara dengan orang lain adalah siswa harus berani misalnya dalam mengungkapkan pendapatnya, di dalam diri anak teliti terliahat anak mulai berani menjawab atau bertanya kepada guru (orang lain). Siswa sudah bisa menceritakan pengetahuan dan pengalamannya, dalam diri anak teliti ini anak kurang mampu dalam menceritakan pengetahuan dan wawasan di sekolah misalnya atau di dalam didepan orang banyak, sebabnya ialah dikarenakan lebih bersifat pemalu dalam diri anak, ragu takut salah dalam perkataan, terutama tidak berani berhadapan dengan orang lain.

Berkaitan dengan narasumber di atas berkembangan berbicara anak di rumah dengan di sekolah tidak sama jauh hampir mirip, sifat anak memang pemalu, namun orangtuanya tetap membimbing anak dalam belajar yaitu dengan cara memprivat belajar kerumah pengajar, dikarenakan adanya kesibukan pekerjaan orangtua tidak dapat membimbing anak setiap hari, kecuali di hari memang ada libur dalam bekerja.

\section{Narasumber ke-4}

Hasil dari observasi dan wawancara peneliti, narasumber ke-4 yang berinisial M berprofesi sebagai petani yang mempunyai anak 3 orang, anak pertama bernisial $S$ yaitu anak yang akan peneliti lakukan, anak kedua berinisial $\mathrm{N}$ belum sekolah dan anak ketiga bernisial U masih bayi sekitar umur 2 tahun. Anak bernisial $S$ ini termasuk berada di kelas rendah yaitu kelas 1 SD,. Ketika wawancara dengan orangtua yaitu ibunya, sistem belajar anaknya tidak harus dipaksakan dalam belajar, namun sudah dibiasakan ketika setelah magrib waktunya belajar dibimbing orangtuanya, anak dengan senang memulai pembelajaran dan ibunya pun merasa nyaman membimbing anaknya ketika belajar.

Pola asuh yang di terapkan oleh orangtua $S$ ini adalah pola asuh Demokratis, karena saling memberkan pemahaman daru belah pihak, orangtua membimbing anak belajar dengan gampang dan anak mau belajar dengan mudah, tidak ada pemaksaan dari orang tua, orangtua anak ini memberikan kebebasan dalam bergaul atau bermain keluar asalkan jangan sampai kelewat batas. Anak disiplin dalam belajar karena dibiasakan sejak awal setelah magrib belajar.

Dalam masa pendemi ini, orangtuanya lebih memperhatikan anak belajar di rumah, ketika masa kerja dipertanian mengharuskan bermalam dikebun, anak dengan sendiri belajar karena sudah dibiasakan. Untuk keterampilan berbicaranya di kelas rendah indikator tujuan pembelajaran berbicara anak berinisial S ini sangat aktif di sekolah dan berni mengungkapkan pendapat dan menceritakan pengalamannya. Ketika seorang guru bercerita yang mungkin memang dianggapnya kurang mengerti atau tidak paham, maka 
dengan berani dia mengajukan pertanyaan kepada gurunya atau kepada orangtuanya ketika belajar di rumah.

Keterampilan berbicara $\mathrm{S}$ di sekolah dengan di rumah sampai saat ini ibunya mengatakan tetap sama dengan di sekolah, dia tetap aktif dalam berbicara dan bertanya dengan orangtuanya jika memang ada yang tidak mengerti. Berkaitan dengan narasumber yang ke-2 ini bahwa pola asuh yang diterapkan ialah demokratis, dan keterampilan anak berbicara di sekolah dan di rumah tetap sama tidak ada perbedaan, asalkan orang tua selalu membimbing di rumah apalagi di saat pendemi ini, anak lebih banyak berdiam diri di rumah saja, tidak beraktifitas sosial dengan yang lain.

\section{Narasumber ke-5}

Hasil dari observasi dan wawancara peneliti, narasumber ke-5 yang berinisial A berprofesi sebagai Guru yang mempunyai anak 2 orang, anak pertama bernisial I dan anak ke dua bernisial L (anak ini yang akan peneliti teliti) sudah memasuki kelas 4 SD. Dalam wawancara ibunya mengatakan sebelum pendemi ada sebenarnya kurang memperhatikan anak dalam belajar, dikarenakan sibuk dalam pekerjaan sebagai PNS dan mengurus pekerjaan rumah tangga, jadinya untuk prestasi saat kurang dan lebih orestasi anak seorang ibu rumah tangga atau petani.

Ketika masa pendemi ini semua aktivitas mengajar dihentikan dan diganti dengan pembelajaran online, ibunya mempunyai waktu dalam membimbing anak, namun anaknya yang malas dalam belajar, malah bermain-main di luar rumah, susah untuk mengajak anak dalam berkompromi soal pembelajaran. Maka orang tua dalam mengajak anak belajar dengan cara jika anaknya ingin belajar atau dengan cara lemah lembut mengajaknya baru mau memulai pembelajaran.

Pola asuh yang diterapkan orangtua ini adalah termasuk pola asuh permisif, ialah orangtua menyajikan dirinya sesuai dengan keinginan anak, orangtua yang tidak menuntut dikarenakan orangtunya sibuk dengan profesi pekerjaanya, dan orangtua kurang mendisiplinkan anak dalam belajar, mengontrol perilaku anak yang rendah. Dalam masa pendemi ini orangtua selalu berusaha agar kebiasaan anak yang dulu malas akan belajar di rumah menjadi sedikit demi sedikit suka dalam belajar meskipun tidak setiap hari belajar.

Indikator pembelajaran berbicara di kelas tinggi ialah berani melakukan sesuatu ketika belajar misalnya dalam bertanya, anak ini sudah berani ketika memang ada yang kurang dia pahami, selalu menanyakn kepada pengajarnya. Untuk indikator menceritakan wawasan, anak ini kurang dikarenakan sulit dalam mengingat kata-kata dalam bercerita, dan untuk menghargai pendapat orang lain , anak ini terlalu keras dan lebih ingin menang sendiri, karena dia merasa bahwa dirinya yang paling benar.

Berkaitan dengan narasumber yang ke-3 ini, anak berinisial L ini, cenderung anaknya pemalas, dikarenakan orangtua yang kurang memperhatikan anaknya dan sibuk dangan pekerjaannya, seharusnya orangtua yang berprofesi guru lebih mudah dalam mendidik anak karena ilmu dalam mendidik telah dikuasainya, orangtua yang memang pekerjaanya padat akan lebih baik menyisihkan waktunya dengan menjadwalkan membimbing anak belajar setiap hari walaupun itu hanya sebentar, agar mempunyai kebiasaan dan tidak akan malas-malasan. Keterampilan berbicara anak dalam diri anak ini sangatlah kurang, dan PR bagi orangtua mengembangkan keterampilan berbicara anak kedepannya.

\section{Narasumber ke-6}

Hasil dari observasi dan wawancara yang dilakukan oleh peneliti, narasumber ini berinisial $\mathrm{H}$, beliau berprofesi sebagai guru MI, beliau memiliki 2 anak, anak pertama 
berusia 10 tahun dan yang terkhir berusia 3 tahun, yang menjadi fokus perhatian peneliti ialah anak yang berusia 10 tahun yang mana anak tersebut duduk di kelas 4 sekolah dasar.

Di masa pandemi ini anak yang berinisial $\mathrm{H}$ sekolah dengan sistem online/daring, sistem sekolah daring yang dilaksanakan $\mathrm{H}$ ialah guru memberikan tugas Via WA di group kelasnya, waktu pengerjaan di batasi yaitu pagi di beri tugas sore di kumpulkan dengan cara cara yang beragam.

Orang tua ini mengatakan bahwa $\mathrm{H}$ ini ketika dirumah suka bergaul, baik dilingkungan sekolah maupun dilingkungan keluarga, akan tetapi sewajarnya anak anak, ia akan merasa pemalu jika berhadapan dengan orang baru, oleh sebab itu ketika anak ini tidak lagi melakukan komunikasi secara tatap muka dengan teman temannya menurut tuturan orang tuanya, $\mathrm{H}$ ini merasa malu jika berhadapan dengan teman teman sebayanya ketika bertemu.

Anak ini full sekolah online senin sampai sabtu, sehingga orang tualah yang membimbing belajar oline anak, dari memerintahkan anak untuk selalu tepat waktu dalam mengumpul tugas onlienya sampai memberikan nasehat nasehat agar anak tetap semangat dalam melaksanakan sekolah online. Jika berbicara tentang keterampilan berbicara anak. $\mathrm{H}$ ini disekolah sangat bagus bahkan ia selalu masuk rengking 1 dan 2 dikelasnya. Cara orang tua dalam membimbing ialah dengan selalu memberikan kesempetan kepada anak untuk tidak bergantung dengan orang lain yang mana dari analisis ini pola asuh yang diberikan orang tua masuk ke kategori demokratis, dan juga anak ini diberikan kelonggaran dalam melakukan sesuatu hal yang ia kehendaki akan tetapi bebas disini tidak serta merta segala sesuatu dibebaskan contohnya ketika $\mathrm{H}$ ini ingin bergaul dengan teman-temannya selalu diizinkan, tetapi jika $\mathrm{H}$ ini tidak ingin mengerjakan tugas atau tidak sekolah tidak pernah diizinkan, sehingga pola asuh orang tua ini pun juga masuk pada kategori permisif yaitu orang tua memberikan kelonggaran atau kebebasan tetapi tetap ada batasannya dan dikontrol penuh oleh orang tua. Tipe ini biasanya bersifat hangat, sehingga seringkali disukai oleh anak

Berkaitan dengan indikator berbicara anak yang berada di kelas tinggi, keterampilan berbicara anak dari dampak 2 pola asuh orang tua tersebut yaitu anak mempunyai keberanian misalnya dalam melakukan komunikasi dengan orang lain. Dampak dari pola asuh permisif anak lebih berani untuk dapat menceritakan pengetahuan yang dimiliki serta anak dapat menyanggah pendapat orang lain atau teman sebayanya. sedangkan dampak dari pola asuh demokratis anak dapat lebih mengahargai pendapat orang lain. dari hasil wawancara dengan orang tua menjelaskan anak mampu mengungkapkan pendapatnya hingga menjelaskan hal-hal yang berhubungan dengan lingkungan bermain sampai pembelajarannya, hal tersebut berdampak karena pola asuh demokratis dan permisif seimbang pada ukuran karakteristik di keluarga tersebut.

\section{Kesimpulan}

Pola Asuh zaman Now yang dimaksud pada judul adalah pola asuh orang tua pada masa Pandemi (Covid-19) yang mengalami pergeseran karena segala aktivitas pendidikan anak dalam hal pendidikan dilakukan secara online artinya berdampak pada pola asuh orang tua tersebut tak terkecuali terhadap keterampilan berbicara anak. Keterampilan berbicara anak termasuk dari 4 keterampilan dalam berbahasa Indonesia. pola asuh orang tua menjadi hal yang penting sekarang khususnya pada masa pandemi karena anak lebih sering menghabiskan waktu di rumah. 
Muhammad Majdi, Hj. Rahimah, Muzdalifah : Pola Asuh Orang Tua “Zaman Now” Terhadap Keterampilan Berbicara Anak Usia Dasar

Hasilnya dari 6 narasumber ditemukan bahwa pola asuh orang tua itu tidak mesti sama untuk mencapai tujuan yang sama. Contohnya dari rekam penelitian 6 narasumber pola asuh orang tua tersebut berbeda dan hasilnya 5 narasumber diantaranya keterampilan berbicara anak tetap stabil dan berkembang. Hasilnya dijabarkan sebagai berikut: Narasumber 1 pola asuh Demokratis, narasumber 2 pola asuh Otoriter, narasumber 3 pola asuh Autoritatif, narasumber 4 pola asuh Demokratis, narasumber 5 pola asuh permisif, dan narasumber 6 pola asuh Demokratis dan Permisif. Hasil yang berbeda terjadi pada Narasumber yang ke-5 berdampak negatif karena kurang tegas dan kurang seimbangnya pengaruh orang tua sehingga orang tua dibawah kendali anak. Sedangkan narasumber yang ke-6 dapat memadukan antara 2 pola asuh orang tua demokratis dan permisif yang mana hasilnya dapat berjalan dengan baik, pada pola asuh permisif berdampak baik karena selain pola asuhnya dipadukan dengan pola asuh demokratis juga orang tua walaupun diberi kelonggaran tetapi tetap memberikan batasan.

Pola asuh orang tua zaman now atau pada masa pandemi sekarang beragam polanya sesuai dengan lingkungan keluarga dan karakteristik dari anak tersebut. Ada yang cocok atau sesuai dengan pola asuh tersebut dengan berdampak kepada kebahasaan anak yang baik. Dan ada juga dengan pola asuh yang sama tetapi hasilnya malah tidak sesuai atau tidak cocok, hal ini kembali kepada karakteristik dari lingkungan keluarga dan anak tersebut. Seperti contoh dari narasumber 5 dan 6.

\section{Daftar Pustaka}

E Lestari dan R Auliana, Hubungan Pola Asuh Orang Tua dengan Prestasi Belajar Siswa Konsentrasi Patiseri SMK Negeri 1 Sewon, Bantul. Jurnal Pendidikan, Http://eprints.uny.ac.id/10617/1/JurnalErmaLestari/pdf. Diakses 13 Januari 2021

E.B, Surbakti, Parenting Anak, (Jakarta: Kompas Gramedia, 2012.

Euis Sunarti, Mengasuh Dengan Hati, Bandung: Elax Media Komputindo, 2004.

Hasanatul Jannah, "Bentuk Pola Asuh Orangtua Dalam Menanamkan Perilaku Moral Pada Anak Usia Dini di Kecamatan Ampek Angkek", dalam Jurnal PG-PAUD FIP, Universitas Negeri Padang, 2016.

Henry Guntur Tarigan, Menulis: sebagai Suatu Keterampilan Berbahasa Bandung: Angkasa, 1986.

Hurlock, Perkembangan Anak, Jakarta:Erlangga, 1978.

Isah Cahyani, modul pembelajaran bahasa Indonesia, Jakarta: direktorat jenderal pendidikan Islam, 2012.

Maimunah Hasan, Pendidikan Anak Usia Dini, Yogyakarta : DIVA Press, 2009. 
Muhammad Majdi, Hj. Rahimah, Muzdalifah : Pola Asuh Orang Tua “Zaman Now” Terhadap Keterampilan Berbicara Anak Usia Dasar

Muhyani, Pengaruh Pengasuhan Orang Tua dan Peran Guru Di Sekolah Menurut Persepsi Murid Terhadap Kesadaran Religius dan Kesehatan Mental, Jakarta: Kementrian Agama Republik Indonesia, 2012.

Nana Syaodih Sukmadinata, Metode Penelitian Pendidikan, Bandung: Remaja Rosdakarya,2015.

Rabiyatul Adawiyah, Poa Asuh Orang Tua dan Implikasinya Terhadap Pendidikan Anak, FKIP ULM Banjarmasin, Jurnal pendidikan, Http://pola-asuh-orang-tua-danimplementasinya-ter/pdf. Diakses 13 Januari 2021

Rita Cahyati dan Rita Kusumah, Peran Orang Tua Dalam Menerapkan Pembelajaran di Rumah Saat Pandemi Covid 19, PG PAUD STIKIP Muhamadiyah Kuningan, Vol.04 No 1 diakses 13 Januari 2021.

Solchan T.W., Pendidikan Bahasa Indonesia di SD, Banten: universitas terbuka press, 2014.

Sugiyono, Metode Penelitian Kualitatif untuk Penelitian yang Bersifat: Eksploratif Interaktif dan Konstruktif, Bandung: Alfabeta, 2017.

Sumiati dkk, Kesehatan Jiwa Remaja Dan Konseling, Jakarta: Trans Info Media, 2014. 